\title{
Selective herbicides to control grass seeds in transplanted tomatoes and peppers'
}

\author{
Li C. Liu and Megh R. Goyal
}

\begin{abstract}
Quizalofop and fluazifop were evaluated as monocot weed control agents in transplanted peppers and tomatoes at the semiarid AES-UPR Fortuna Agricultural Substation. An additional trial was conducted to evaluate a sequential treatment of metribuzin and fluazifop for multiple weed species control in tomatoes. In the first two trials, both quizalofop and fluazifop provided an excellent control of grass species Echinochloa colona, Digitaria sanguinalis, Eleusine indica, and Leptochloa filiformis. These weeds were controlled with quizalofop at 0.112 and $0.224 \mathrm{~kg} \mathrm{ai} / \mathrm{ha}$ and with fluazifop at 0.28 and $0.56 \mathrm{~kg}$ ai/ha. None of the herbicides produced any apparent injury to peppers and tomatoes. The sequential treatment of metribuzin and fluazifop, 15 days later at $0.56 \mathrm{~kg}$ ai/ha, was highly effective against both grass and broadleat weeds in tomatoes. This treatment caused no apparent injury.
\end{abstract}

\section{RESUMEN}

Evaluación de herbicidas selectivos para tomates y pimientos regados por goteo

En 1985-86, en la subestación experimental de Fortuna, se evaluaron los herbicidas "quizalofop" y "fluazifop" para combatir las malezas gramíneas en siembras de tomates y pimiento regadas por goteo. Además, se evaluaron las aplicaciones en serie de "metribuzin" y "fluazifop" para combatir las gramíneas y los yerbajos de hoja ancha en tomateras. En las primeras dos pruebas, la represión con "quizalofop" y "fluazifop" fue muy efectiva contra las gramíneas arrocillo, pendejuelo, pata de gallina y yerba de hilo. Estas gramíneas se reprimieron eficazmente con "quizalofop" a razón de 0.112 a $0.224 \mathrm{~kg}$. p.a./ha. y "fluazifop" a razón de 0.28 a 0.56 kg. p.a./ha. Con estas pruebas ninguno de estos herbicidas le causó fitoxicidad al tomate ni al pimiento. En otra prueba, el tratamiento de metribuzin y fluazifop aplicados en serie, ambos herbicidas a razón de $0.58 \mathrm{~kg}$. p.a./ha., propició una represión muy efectiva de las gramíneas y yerbajos de hoja ancha en tomateras.

\section{INTRODUCTION}

Peppers (Capsicum annuum L) and tomatoes (Lycopersicon esculentum Mill) are comparatively non-robust hybrid plants that compete poorly with vigorous wild and native weeds under Puerto Rico conditions. Consequently, weed competition becomes a major constraint on local production of these crops. The critical period of weed competition

'Manuscript submitted to Editorial Board 2 December 1989.

2Plant Physiologist and Agricultural Engineer respectively, Agric. Exp. Stn. University of Puerto Rico, Río Piedras, P. R. 
varies from 24 to 36 days after transplanting in peppers $(6,7)$ and tomatoes (9). Manual methods to control weeds are tedious, expensive and frequently ineffective because of labor shortage at the critical time.

Chemical weed control has been shown to be economical and efficient for the control of weeds in these crops in Puerto Rico (11). Although some preemergence herbicides were effective in tomatoes and peppers $(4,5,8,10)$, local farmers often prefer to wait until weeds become established before applying postemergence herbicides.

Local postemergence use of glyphosate and paraquat has caused crop injury or yield reduction in peppers and tomatoes $(10,13)$. Development of the selective postemergence herbicides quizalofop and fluazifop, in the early $80 \mathrm{~s}$, has provided safe and effective agents for grass control in broadleaved crops $(11,12)$. Both have been used in agronomic and horticultural crops in the U. S. (14). Braithwaite (2) in Trinidad found that quizalofop at rates of 0.05 to $0.10 \mathrm{~kg}$ ai/ha gave excellent control of annual and perennial grasses in 14 crops that included peppers and tomatoes.

The purpose of this study was to evaluate quizalofop $2-\{4[(6-$ chloro2-quinoxalinyl) oxy] phenoxy\} propanoic acid and fluazifop 2-[ 4[5-(trifluoromethyl) 2-pyridinyl] oxyl] phenoxy] propanoic acid for the postemergence control of grass weeds in peppers and tomatoes. Two field trials were performed. An additional third trial was designed to evaluate sequential usage of metribuzin and fluazifop (the former also a postemergence compound) in variably-timed combination with fluazifop. This combination was thought to have potential for expanding weed-control options for growers in Puerto Rico.

\section{MATERIALS AND METHOD}

First Experiment

The first experiment was conducted on a San Antón soil series (34\% sand, $33 \%$ silt, $33 \%$ clay, $2.1 \%$ organic matter, and $\mathrm{pH} 7.1$ ) in the semiarid south coast. The seedbed was prepared by plowing followed by disc harrowing in two directions. It was then partitioned into $3.1 \times 3.7 \mathrm{~m}$ plots. When planted, each plot consisted of 40 pepper transplants arranged in two double rows. Plant spacing was $30 \mathrm{~cm}$ within the row. The experimental design was a randomized complete block with four replications of each treatment. Pepper seedlings (Cv. Cubanelle) 42 days old were transplanted 19 February 1986 . They were irrigated by a drip system as described by Goyal (5). Quizalofop (Assure $0.8 \mathrm{lb} / \mathrm{gal}$ ) at 0.112 and $0.224 \mathrm{~kg}$ ai/ha and fluazifop (Fusilade $20001 \mathrm{E}$ ) at 0.28 and $0.56 \mathrm{~kg}$ ai/ha were applied in aqueous solution with a knapsack sprayer. Weeds were sprayed at 5- to 7-leaf stage. A surfactant, X-77, was added to each herbicide solution at a rate of $0.6 \mathrm{ml}$. The final spray volume was equivalent to $468 \mathrm{l} / \mathrm{ha}$. Herbicides were applied under a clear sky with occasional cloudiness. One week prior to herbicide applications, broadleaf 
weeds were removed manually as neither herbicide controls them. Check plots were hand-weeded three times at 1-month interval after transplanting. All plots were fertilized in two increments consisting of $392 \mathrm{~kg} / \mathrm{ha}$ of a 10-10-8 commercial formulation. The first increment was applied 26 February 1986, 1 week after transplanting, and the second 26 March 1985. The plots were irrigated as needed when moisture tension attained 50 cbars. Fungicides and insecticides were applied in accordance with recommended practices for insular vegetable production $(1,3)$. Data for weed control and phytotoxicity were recorded as numerical ratings at 4 weeks after herbicide treatment. Peppers were hand-picked. There were six pickings at 14-day intervals, beginning 21 April 1986, 60 days after transplanting. The weight of marketable fruits was recorded for each plot.

\section{Second Experiment}

The second experiment was also performed at the Fortuna Substation, with tomatoes as the test crop. The same soil series, plot size and experimental design were used as in the first experiment. Plants were similarly drip-irrigated. Each plot consisted of 20 tomato plants arranged in two rows. Tomato seedlings (Cv. Duke) 28 days old were transplanted 13 December 1985. Quizalofop and fluazifop were applied at the rates used in the first experiment. Broadleaf weeds were removed manually as in the first experiment. Hand-weeded control plots were weeded three times (at 31, 64 and 79 days after transplanting). All tomato plants were staked and supported by nylon string 3 weeks after transplanting. A commercial fertilizer formulation (10-10-8) was applied once at the rate of $224 \mathrm{~kg} / \mathrm{ha}$. This was followed by two applications of Nutri-leaf solution $(1.3 \mathrm{~g} / \mathrm{L}) \mathrm{i}$ and 2 months later. Fungicides and insecticides were applied either weekly or biweekly in accordance with standard recommendations $(1,3)$. Tomatoes were hand-picked. Pickings were performed four times at 14-day intervals, the first about 77 days after transplanting. Marketable fruit weights were recorded for all treatments.

\section{Third Experiment}

This study was established at the same location and time of the second experiment. Identical plot size and experimental design were also used. The herbicide treatment consisted of a sequential application of metribuzin and fluazifop. Metribuzin (Sencor $50 \mathrm{~W}$ ) at $0.56 \mathrm{~kg} / \mathrm{ha}$ was applied 15 Jan. 1986 and fluazifop at $0.56 \mathrm{~kg} / \mathrm{ai} / \mathrm{ha} 30 \mathrm{Jan} .1986$. Establishment of hand-weeded control plots and the management of treated plants was consistent with experiment 2 . Weed control and crop phytotoxicity values were recorded 1 month after each herbicide application. Tomatoes were hand-picked four times. Weight yields of marketable tomatoes were recorded. 


\section{RESULTS AND DISCUSSION}

\section{First field experiment}

The predominant grass species in the experimental plots were jungle rice [Echinochloa colona (L) Link], crabgrass [Digitaria sanguinalis (L) Scop.], goose grass [Eleusine indica (L) Gaertn.] and sprangletop [Leptochloa filiformis (Lam) Beauv.]. Quizalofop at 0.112 and $0.224 \mathrm{~kg}$ ai/ha, gave very good control of these grasses (table 1). Fluazifop at the 0.28 and $0.56 \mathrm{~kg}$ ai/ha rates also provided excellent control of the same grasses. Neither herbicide, as expected, was effective against broadleaf weeds, which included pigweed (Amaranthus dubius), spider flower (Cleome gynandra (L), horse purslane (Trianthema portulacastrum L) and red spiderling (Boerhavia coccinea Mill.). The herbicide treatments produced no phytotoxicity symptoms in peppers, but some yield repression was noted. The highest yield was recorded in hand-weeded reference plots. This treatment does not differ significantly from fluazifop at 0.56 $\mathrm{kg}$ ai/ha. However, quizalofop at $0.112 \mathrm{~kg}$ ai/ha produced significantly fewer marketable peppers than all other treatments. The non-weeded plots produced the lowest pepper yield.

\section{Second field experiment}

Quizalofop at both experimental rates gave excellent control of the grass species noted in the pepper experiment (table 2). Fluazifop treatments were similarly effective. No herbicide injury to tomatoes was observed (table 2). Hand-weeded reference plots again produced the high-

TABLE 1.-Effect of herbicides quizalofop and fluazifop on weed control, crop phytotoxicity and yield of irrigated peppers on the semi-arid south coast of Puerto Rico

\begin{tabular}{lccc}
\hline Treatment & Grass control & Phytotoxicity & Yield \\
\hline $\begin{array}{l}\text { Quizalofop } \\
\quad 0.112 \mathrm{~kg} \text { ai/ha }\end{array}$ & 87 & $\%$ & $\mathrm{~kg} / \mathrm{ha}$ \\
$\begin{array}{l}\text { Quizalofop } \\
\quad 0.224 \mathrm{~kg} \text { ai/ha }\end{array}$ & 92 & 0 & $10,886 \mathrm{~d}^{3}$ \\
$\begin{array}{l}\text { Fluazifop } \\
\quad 0.28 \mathrm{~kg} \text { ai/ha }\end{array}$ & 93 & 0 & $14,134 \mathrm{bc}$ \\
$\begin{array}{l}\text { Fluazifop } \\
\quad 0.56 \mathrm{~kg} \text { ai/ha }\end{array}$ & 97 & 0 & $13,082 \mathrm{bc}$ \\
$\begin{array}{l}\text { Weeded check } \\
\text { Non-weeded check }\end{array}$ & 90 & 0 & $15,389 \mathrm{ab}$ \\
\hline
\end{tabular}

'Weed control ratings are based on a scale of 0 to 100 , where $0=$ no control and 100 $=$ total control.

${ }^{2}$ Phytotoxicity evaluations are based on a scale of 0 to 100 , with $0=$ no phototoxicity and $100=$ total mortality.

${ }^{3}$ Means bearing the same letter or letters do not differ significantly at the 0.05 probability level. 
TABLE 2.-Effecl of quizalofop and fluazifop on weed control, phytotoxicity and yield of tomatoes on the south coast of Puerto Rico

\begin{tabular}{lccc}
\hline Treatment & Grass control & Phytotoxicity & Yield \\
\hline $\begin{array}{l}\text { Quizalofop } \\
\quad \%\end{array}$ & 93 & $\%$ & $k \mathrm{~kg} / \mathrm{ha}$ \\
$\begin{array}{l}\text { Quizalofop } \\
\quad 0.224 \mathrm{~kg} \text { ai/ha }\end{array}$ & 97 & 0 & $24,882 \mathrm{~b}^{1}$ \\
$\begin{array}{l}\text { Fluazifop } \\
\quad 0.28 \mathrm{~kg} \text { ai/ha }\end{array}$ & 95 & 0 & $27,158 \mathrm{ab}$ \\
$\begin{array}{l}\text { Fluazifop } \\
\quad 0.56 \mathrm{~kg} \text { ai/ha }\end{array}$ & 98 & 0 & $26,671 \mathrm{ab}$ \\
Weeded check & & & \\
Non-weeded check & 95 & 0 & $29,570 \mathrm{ab}$ \\
\hline
\end{tabular}

'See table 1.

est tomato yield of marketable fruits (table 2). Moderately lower yields were obtained from heribicde plots, particularly from quizalofop at 0.112 $\mathrm{kg}$ ai/ha.

\section{Third Experiment}

The sequential treatment with metribuzin and fluazifop at $0.56 \mathrm{~kg}$ ai/ha each, provided excellent control of both grasses and broadleaved weeds (table 3). In this treatment metribuzin first controlled broadleaf weeds and fluazifop subsequently eliminated grasses. Again, no tomato plants were visually injured by this treatment (table 3 ). The highest tomato yield was again produced in conjunction with handweeding. The second highest yields were obtained from the sequential treatment of metribuzin and fluazifop. The non-weeded control plots yielded the fewest tomatoes.

Results from the first two experiments suggest important potentials of quizalofop and fluazifop for selective postemergence control of grass

TABLE 3.-Effect of a sequential application of metribuzin and fluazifop on weed control phytotoxicity and yield of tomatoes on the south coast of Puerto Rico

\begin{tabular}{lcccc}
\hline Treatment & Grasses & Broadleaves & Phytotoxicity & Yield \\
\hline $\begin{array}{c}\text { Metribuzin } \\
0.56 \mathrm{~kg} \mathrm{ai} / \mathrm{hat} \\
+\end{array}$ & 95 & 90 & $\%$ & $\mathrm{~kg} / \mathrm{ha}$ \\
$\begin{array}{l}\% \\
\text { fluazifop }\end{array}$ & & & 0 & $33,176 \mathrm{a}^{1}$ \\
$\quad \begin{array}{l}0.56 \mathrm{~kg} \text { ai/ha } \\
\text { Weeded check }\end{array}$ & & & & \\
Non-weeded check & 98 & 95 & & \\
\hline
\end{tabular}

See table 1. 
weeds in peppers and tomatoes under semi-arid P. R. conditions. Local registration of both herbicides remains pending completion of residue data analyses. The optimal tested rate for both crops under typically prevailing weed situations appears to be $0.224 \mathrm{~kg}$ ai/ha for quizalofop and $0.56 \mathrm{~kg}$ ai/ha for fluazifop in accordance with the results of this study. Braithwaite (2) reported the optimum rate of quizalofop was between 0.05 to $0.10 \mathrm{~kg}$ ai/ha for the same crop species. Our present results suggest that a slightly higher rate of both herbicides offers better weed control. In a previous experiment on tomato, Jackson and Sierra (4) found that metribuzin was less effective on gxass species, particularly goose grass. Combination of metribuzin and fluazifop appears to be a logical approach for controlling both broadleaves and grasses.

The outstanding results with metribuzin and fluazifop combined suggest that this type of treatment should be adopted by our growers as soon as fluazifop is registered locally. However, for peppers, there is no comparable promising compound for postemergence control of broadleaf weeds in combination with fluazifop. Future herbicide research in this area should be directed to identifying a good selective postemergence herbicide for broadleaf weeds in peppers, and to test it in sequential treatments with fluazifop.

\section{LITERATURE CITED}

1. Acín-Díaz, N., H. O'Farrill-Nieves y T. Montalvo-Zapata, 1984. Plaguicidas con permiso de uso en hortalizas. Plaguicidas al Dia. 5 (2) 3-5.

2. Braithwaite, R. A. I., 1985. Assure-a new selective herbicide for the control of annual and perennial grass weeds in broadleaf crops. Proc. 21st meeting of Caribbean Food Crops Soc., in press.

3. Estación Experimental Agrícola., 1976. Conjunto tecnológico para la producción de hortalizas. Publ. 102, Univ. P. R.

4. Jackson, G. C. and C. Sierra-Morales, 1979. Tolerance of tomato eultivars to preemergence application of metribuzin. Proc. 18th annual meeting of Caribbean Food Crops Soc. 16: 113-17.

5. Goyal, M. R., 1983. Labor-input requirements for experimental production of summer peppers under drop irrigation. J. Agric. Univ. P. R. 67 (1): 22-7.

6. Liu, L. C., 1984. Control de malezas en tomatoes y pimientos. Revista del Colegio de Agrónomos de Puerto Rico 11 y 27.

7. —_ J. González-Ibáñez and M. R. Goyal, 1984. Weed competition in transplanted sweet peppers. Proc. 20th annual meeting of Caribbean Food Crops Soc. 20: 291-96.

8. _ M. Antoni-Padilla., M. R. Goyal and J. González-Ibáñez. 1987. Integrated weed management in transplanted tomatoes and peppers. J. Agric. Univ. P. R. 71 (4): $349-58$.

9. Lugo, M. L., L. C. Liu and L. A. Almodóvar, 1988. Periodo crítico de competencia de las malezas en el tomate de trasplante. J. Agric. Univ. P. R. 72: 291-96.

10. Orengo-Santiago, E., N. Semidey and L. A. Almodovar, 1987. Influence of glyphosate and paraquat pre-transplant treament on weed control and pepper yields. J. Agric. Univ. P. R. 71 (1): 65-73.

11. Plowman, R. E., W. C. Stonebridge and J. N. Hawtree, 1980. Fluazifop-butyl a new selective herbicide for the control of annual and perennial grass weeds. Proc. British Crop Protection Conf. Weeds 1: 29-37. 
12. Sakata, G., K. Makino, Y. Ura., T. Ikai and K. Kawamura, 1983. Proc. 10th. Int. Congr. Plant Prot. pp 315-23.

13. Semidey, N. and L. A. Almodóvar. 1987. Glyphosate on tomato and sweet pepper yields. J. Agric. Univ. P. R. 71 (2): 235-37.

14. Weed Science Soc. of America. 1983. Herbicide Handbook Fifth ed, Champaign, Illinois. 